\title{
Inequality in the Legal Order: Some Further Analysis and Commentary
}

\author{
William C. Bailey \\ Cleveland State University, w.bailey@csuohio.edu \\ Follow this and additional works at: https://engagedscholarship.csuohio.edu/clsoc_crim_facpub \\ Part of the Sociology Commons
}

How does access to this work benefit you? Let us know!

\section{Publisher's Statement}

Published as Bailey, William C. 1981. "Inequality in the Legal Order - Some Further Analysis and Commentary." Social Problems 29(1):51-60. (c) 1981 by the Regents of the University of California. Copying and permissions notice: Authorization to copy this content beyond fair use (as specified in Sections 107 and 108 of the U. S. Copyright Law) for internal or personal use, or the internal or personal use of specific clients, is granted by the Regents of the University of California for libraries and other users, provided that they are registered with and pay the specified fee via Rightslink® on JSTOR (http://www.jstor.org/r/ucal) or directly with the Copyright Clearance Center, http://www.copyright.com.

\section{Original Citation}

Bailey, William C. 1981. "Inequality in the Legal Order: Some Further Analysis and Commentary." Social Problems 29(1):51-60.

\section{Repository Citation}

Bailey, William C., "Inequality in the Legal Order: Some Further Analysis and Commentary" (1981). Sociology \& Criminology Faculty Publications. 6.

https://engagedscholarship.csuohio.edu/clsoc_crim_facpub/6

This Article is brought to you for free and open access by the Sociology \& Criminology Department at EngagedScholarship@CSU. It has been accepted for inclusion in Sociology \& Criminology Faculty Publications by an authorized administrator of EngagedScholarship@CSU. For more information, please contact library.es@csuohio.edu. 


\title{
INEQUALITY IN THE LEGAL ORDER: SOME FURTHER ANALYSIS AND COMMENTARY
}

\author{
WILLIAM C. BAILEY \\ Cleveland State University
}

\begin{abstract}
I challenge David Jacobs' support for the conflict model of the legal order, finding serious limitations in his cross-sectional test of the model. To avoid these limitations and to extend the scope of Jacobs' study, I (1) apply his model to four additional crimes against persons and property; (2) examine race as an additional dimension of social inequality; and (3) consider how levels of crime might influence imprisonment ratios, a factor Jacobs ignored. I find no support for the hypothesis that race is a significant determinant of state imprisonment practices. Nor do I find income inequality a significant factor in imprisonment for crimes against persons and property, except in the case of larceny.
\end{abstract}

In "Inequality and the legal order: An ecological test of the conflict model," David Jacobs (1978) hypothesizes that "the more there are differences in economic resources and economic power, the more one can expect that the criminal codes will be administered in a way that pleases monied elites." Specifically, violators of property crimes are more likely to be punished where economic power and resources are distributed unequally. Jacobs emphasizes the importance of economic inequality because "as long as money almost automatically confers power in western society . . . its unequal distribution ought to lead to outcomes preferred by the rich." He also emphasizes the punishment of property crimes because "one major guarantee of the supremacy of an economic elite is property," and it stands to reason that the authorities will "make greater efforts to insure that violators of the property codes are sanctioned" (1978:516).

Jacobs examined the relationship between income inequality and state imprisonment ratios for burglary and larceny using cross-sectional data for 1960 . He introduced four other variables into the analysis to control for spuriousness of the relationship between income inequality and certainty of imprisonment: (1) the percentage of residents living in large cities; (2) percent change in the population from 1950 to 1960; (3) police per capita; and (4) resource level-mean income. His analysis of 47 states revealed a significant positive relationship between income inequality and imprisonment ratios for both burglary and larceny, with income inequality being the best predictor of imprisonment. When only non-southern states were considered $(n=35)$, however, this pattern was altered somewhat for burglary. Jacobs argues that the non-significant findings for burglary for these states are not inconsistent with the conflict hypothesis, since "victimization data indicate that groups with less money are the most frequent victims of this crime in nonsouthern areas" (1978:521, author's emphasis). That is, "differences in economic advantage and power only predict imprisonment ratios for a crime of which a disproportionate number of victims are affluent" (1978:522).

\section{THE PRESENT INVESTIGATION}

While Jacobs should be commended for bringing a different research method to this subject, his investigation suffers from a number of limitations: ${ }^{1}$

1) Can the relationship Jacobs finds between income inequality and imprisonment ratios for larceny and burglary be generalized to other offenses? Jacobs argues that "because survey evidence invariably indicates that the poor are much more likely to be victims of crimes of

1. Because my critique of Jacobs' study is primarily methodological in nature, the reader is referred to his article for a brief examination of the conflict perspective of the legal order and the theoretical basis of our two investigations. 
violence, the association between inequality and the imprisonment ratios for these crimes should be noticeably weaker" (1978:516). He fails, however, to test this assertion by considering violent crimes. To address this question, I applied Jacobs' model to (1) two violent crimes, murder and assault; (2) one additional property crime, auto theft; and (3) robbery, which may be considered either a property or a violent crime.

2) Jacobs used the Gini coefficient of income inequality as a measure of economic inequality, but he did not simultaneously consider race as an additional dimension of inequality. He indicates that he considered race in his model, but that "variables like percent non-white are too collinear with the index of inequality to be used in the same equation $(r=.78)$." In addition, Jacobs reports that, when he substituted percent non-white population for the inequality variable, "the index of inequality does better when independent variables are ranked according to the strength of their coefficients." Thus, he concludes, "the racial aspect of inequality is not a very important determinant of the imprisonment ratios" (1978:520). While this may be correct, Jacobs' conclusion about the relative importance of race and income inequality on imprisonment cannot be drawn from his analysis. The correlation of $r=.78\left(r^{2}=.61\right)$ does not provide sufficient evidence that income inequality and non-white population cannot both be entered into the same equation due to collinearity. On the contrary, a sizable proportion of the variation - nearly 40 percent -in either of these variables cannot be accounted for by the other. In addition, because Jacobs did not simultaneously consider both income inequality and race in his analysis, his findings cannot support the claim that income inequality is a more important determinant of imprisonment. To remedy this situation, I consider both variables simultaneously.

3) Jacobs recognizes that four other factors may influence variations in imprisonment ratios: (1) It may be more difficult to apprehend offenders in large cities where social control is more difficult. (2) Imprisonments may be higher where there is a higher proportion of law enforcement officers. (3) More resources may be applied to crime control where there is a larger tax base. (4) Social control is likely to be more difficult where immigration has been high. To these four variables I would add a fifth consideration that has received some attention in the recent general deterrence literature - the influence of crime rates on the certainty of legal sanctions, including imprisonment (Ehrlich, 1973, 1975; Fisher and Nagin, 1978; Logan, 1972, 1975; Nagin, 1978). Not only may the certainty of arrest, conviction, and imprisonment influence crime rates (deterrence), but the level of crime may also influence the level of arrests, convictions, and imprisonments due to "system overload." Indeed, some recent investigations have found the inverse relationship between the certainty of legal sanctions and crime rates is due more to the effect of crime rates on the certainty of arrest and imprisonment than the effect of the certainty of arrest and imprisonment on offense rates (Logan, 1975; Nagin, 1978). To consider this reciprocal relationship, I introduced the index crime rate for year t-1 (1959) as an additional control variable in the analysis. ${ }^{2}$

4) When Jacobs considered only non-southern states $(n=35)$ he did not find a significant positive relationship between income inequality and imprisonment for burglary. He attributes this to the fact that in non-southern states, victim survey data do not show victims of burglary to be at higher income levels. In contrast, in southern states, victims of burglary are at higher income levels. Accordingly, Jacobs argues that the relationship between income inequality and

2. The crime rate measure used is the total number of the following types of offenses per 100,000 population: murder, assault, forcible rape, robbery, burglary, larceny, and auto theft. Note that I have used the index crime rate lagged by one year ( $\mathrm{t}-1)$ in examining the effect of crime on imprisonment ratios. Had I considered crime rates and imprisonment ratios in the same year, I would have encountered the as-yetunresolved methodological difficulty of separating the deterrent effect of the certainty of imprisonment on offense rates from the effect of crime rates on imprisonment ratios (Greenberg et al., 1980; Logan, 1975; Nagin, 1978). 
burglary imprisonment ratios would differ for the two regions of the country. Jacobs' conclusion may be correct, but the method he uses to test this question is inefficient, and possibly misleading. To illustrate: $\mathrm{He}$ first examined 47 states and then repeated the analysis, excluding 12 southern jurisdictions. This control procedure does remove southern states, but it also results in substantial loss of degrees of freedom $(n=35)$. As well, by excluding southern states from the subsequent analysis, it remains unclear to what extent Jacobs' new findings are a result of: (1) a different form of the relationship between income inequality and imprisonment ratios in the two regions of the country; and (2) examining different ranges in the inequality, imprisonment, and control variables for southern and non-southern states. To address these questions more efficiently, Jacobs should have (1) computed a regional dummy variable in which non-southern and southern states are differentiated by a $0 / 1$ weighting; (2) multiplied the region and income inequality (Gini) values to form an interaction variable; and (3) introduced this computed variable into the multivariate analysis to determine if there is a significant interaction between income inequality and region. This is the procedure I have used to extend Jacobs' analysis.

While part of my investigation is exploratory, I advance the following working hypotheses: First, consistent with Jacobs' findings and the conflict model, I expect a significant positive relationship between income inequality (and non-white population) and certainty of imprisonment for each index crime. Second, for the same reasons Jacobs suggests, I predict imprisonment ratios to be (1) positively related to police per capita and mean income (a proxy variable for resources available for crime control); and (2) negatively related to the proportion of state residents living in large cities and percent change in population for the last 10-year period. Third, if the level of crime does affect the ability of the criminal justice system to effectively deal with crime ("system overload"), I expect a significant negative relationship between crime rates (for year t-1) and imprisonment ratios (for year $t$ ). Fourth, if there are differences between southern and nonsouthern states in patterns of victimization that influence the hypothesized relationship between income inequality and imprisonment ratios, then the region-income inequality interaction variable should provide a better predictor of imprisonment ratios than simply income inequality.

\section{METHOD}

To extend Jacobs' analysis, data were required for imprisonment ratios, income inequality, and the control variables. As in Jacobs' study, I computed imprisonment ratios by dividing the number of prison admissions for each crime by the number of crimes known to the police. Imprisonment and offense data were taken from figures issued by the Federal Bureau of Prisons and Federal Bureau of Investigation, respectively. ${ }^{3}$

The income inequality measure used here is the conventional Gini coefficient which assesses income disparity/concentration in each state. Gini values for 1960 came from figures reported by Janish and Kau (1973). Data for the control variables came from figures issued by the following offices of the U.S. Department of Commerce: per capita income data from the Office of Business Economics (1966), and data on state population living in places of 50,000 or more, percent change in state population during the previous 10 -year period, percent non-white population, and police per capita figures from the U.S. Bureau of the Census $(1961,1964) .{ }^{4}$ Crime rate data for

3. Due to missing imprisonment data for 1960 for Alaska and Hawaii, these two states were excluded from the analysis. Although not a state, the District of Columbia was included as an additional jurisdiction in the analysis.

4. Whereas Jacobs used mean personal income data computed from Internal Revenue statistics as his income measure, I use per capita income figures. Because both mean personal income and per capita income can be considered to be reasonable proxy variables for the level of resources that states apply to crime control, I see no a priori reason why either of these variables would be preferable. I chose the per capita income measure solely because these data were readily available in Department of Commerce publications. 
major felonies for year t-1 (1959) were taken from Federal Bureau of Investigation's $(1959,1960)$ Uniform Crime Reports. A regional variable divided states into southern (value $=1$ ) and nonsouthern (value $=0$ ) jurisdictions. ${ }^{5}$ Finally, a region --income inequality interaction variable was computed by multiplying the values for the Gini coefficient and the regional dummy variable.

The analysis proceeded through a series of multiple regressions. First, I examined Jacobs' model of imprisonment for each index offense (Model I). Second, I repeated the analysis including the region-income inequality interaction variable (Model II). ${ }^{6}$ Third, I examined Jacobs' model further by adding the index crime rate for year $\mathrm{t}-1$ and non-white population as control variables (Model III).

\section{FINDINGS}

Table 1 shows the results of the analysis for each of the three models. I expected a significant positive relationship between income inequality and imprisonment ratios but this is only partially borne out for Model I. The beta coefficients are positive for burglary and larceny and auto theft, but only for burglary is the relationship statistically significant. For larceny, the largest beta is for income inequality, but this coefficient is not significant at $\mathbf{P}<.05$. In contrast, two variables are better predictors of imprisonment for auto theft, with the coefficient being positive (as expected) and statistically significant for the resource level variable.

Jacobs argues that, because the victims and offenders of violent crimes are more economically similar than their counterparts for property crimes, the positive relationship between income inequality and imprisonment ratios for violent crimes should be weaker. Model I does not support this prediction for murder and assault, nor for robbery which may also be considered a crime against persons. On the contrary, for these three offenses there is an inverse relationship between income inequality and imprisonment ratios. Although these negative coefficients are not statistically significant, they do not provide support for the conflict model.

For Model II, where a region-income inequality variable is considered, the findings are again mixed. ${ }^{7}$ For each property crime (including robbery), the interaction variable is positively

5. The following 17 jurisdictions are classified by the Bureau of Census as southern: Alabama, Arkansas, Delaware, District of Columbia, Florida, Georgia, Kentucky, Louisiana, Maryland, Mississippi, North Carolina, Oklahoma, South Carolina, Tennessee, Texas, Virginia, West Virginia.

6. Strictly speaking, multiple regression requires that the independent variables entered into a regression equation be orthogonal (independent). Seldom, if ever, however, is this assumption strictly met in actual research applications, with multiple regression proving to be quite robust even when independent variables are highly correlated (Farrar and Glauber,1967; Haitovsky, 1969). To determine if income inequality and percent non-white population are too collinear (dependent) to be entered into the same regression equation, a series of auxiliary regressions were performed. First, to remove the effect of race (non-white population) from income inequality (Gini values), income inequality was regressed against non-white population and residual Gini values were computed. This procedure made non-white population and income inequality independent $(r=-.002)$ from one another. Second, the residual Gini values were substituted for the original Gini values in the regressions for each offense. The assumption behind this procedure is that, if income inequality (apart from race) is a significant predictor of imprisonment ratios, then removing the effect of race from inequality should not alter Jacobs' findings. Hence, as Jacobs interprets the conflict model, it is income inequality and not race that affects imprisonment ratios. This procedure produced results consistent with the findings reported in Tables 1 and 2 for both income inequality and non-white population and the other independent variables. Thus, I conclude that non-white population and income inequality are not too collinear to be entered in the same equation.

7. For Model II (and Model III), where the possible interaction effect between region and income inequality is considered, standardized coefficients are reported for (1) the interaction variable, (2) southern states, and (3) non-southern states. Because the region variable differentiates non-southern and southern states by a $0 / 1$ weighting respectively, a positive sign for the coefficients for the interaction variable indicates that there is a more substantial relationship between income inequality and imprisonment ratios in southern jurisdictions. Conversely, if the coefficients are negative for the interaction variable, the relationship between income inequality and imprisonment ratios is more substantial in non-southern states. For each region, the coefficients indicate the direction and the magnitude of the relationship between income inequality and imprisonment ratios. 
TABLE 1

Multiple Regression Results for Three Models of

Imprisonment Ratios for Six Index Offenses, 1960

\begin{tabular}{|c|c|c|c|c|c|c|}
\hline Independent Variables & Murder & Assault & Robbery & Burglary & Larceny & $\begin{array}{l}\text { Auto } \\
\text { Theft }\end{array}$ \\
\hline \multicolumn{7}{|l|}{ MODEL I } \\
\hline Economic Inequality (Gini) & -.180 & -.123 & -.023 & $.458 a$ & .385 & .217 \\
\hline Percent Residents of Large Cities & -.249 & -.432 & -.428 & $-.516 a$ & -.166 & -.267 \\
\hline Percent Change in Population & -.104 & -.145 & -.158 & -.123 & -.122 & -.010 \\
\hline Police Per Capita & -.176 & .028 & .056 & .177 & .194 & -.214 \\
\hline Resource Level (Per Capita Income) & .183 & .111 & .092 & -.030 & -.247 & $.717 a$ \\
\hline $\mathrm{R}^{2}$ & .147 & .169 & .152 & $.477 c$ & $.363 b$ & .125 \\
\hline \multicolumn{7}{|l|}{ MODEL II } \\
\hline Economic Inequality \& Region & -.115 & -.227 & .310 & $.514 \mathrm{a}$ & $.500 \mathrm{a}$ & .003 \\
\hline Southern States & -.194 & -.153 & .018 & .526 & .451 & .217 \\
\hline Non-Southern States & -.079 & .074 & -.292 & .012 & -.049 & .214 \\
\hline Percent Residents of Large Cities & -.248 & -.430 & -.430 & $-.519 a$ & -.169 & -.267 \\
\hline Percent Change in Population & -.010 & -.137 & -.171 & -.142 & -.141 & -.010 \\
\hline Police Per Capita & -.163 & .053 & .021 & .118 & .138 & -.215 \\
\hline Resource Level (Per Capita Income) & .181 & .106 & .098 & -.020 & -.237 & $.717 a$ \\
\hline $\mathrm{R}^{2}$ & .150 & .183 & .179 & $.552 \mathrm{c}$ & $.433 \mathrm{c}$ & .125 \\
\hline \multicolumn{7}{|l|}{ MODEL III } \\
\hline Economic Inequality \& Region & -.164 & -.236 & .242 & .367 & $.532 \mathrm{a}$ & -.158 \\
\hline Southern States & -.045 & -.107 & .145 & .339 & .537 & .107 \\
\hline Non-Southern States & .119 & .129 & -.097 & -.028 & .005 & .265 \\
\hline Percent Residents of Large Cities & -.097 & -.391 & -.269 & $-.461 \mathrm{a}$ & -.153 & -.145 \\
\hline Percent Change in Population & .256 & -.046 & .215 & .046 & -.119 & .326 \\
\hline Police Per Capita & .101 & .126 & .281 & .074 & .207 & -.139 \\
\hline Resource Level (Per Capital Income) & .179 & .104 & .102 & .029 & -.252 & $.763 a$ \\
\hline Percent Non-White Population & -.065 & -.026 & -.027 & .289 & -.096 & .246 \\
\hline Index Crime Rate, 1959 & $-.634 a$ & -.162 & $-.680 \mathrm{a}$ & -.300 & -.050 & -.567 \\
\hline $\mathrm{R}^{2}$ & .241 & .189 & .284 & $.594 \mathrm{C}$ & $.436 \mathrm{~b}$ & .216 \\
\hline
\end{tabular}

Significance Levels: $a=P<.05 ; b=P<.01 ; c=P<.001$.

associated with imprisonment ratios, and the betas are statistically significant for burglary and larceny. For burglary there is a moderate to strong relationship between income inequality and imprisonment for southern states (.526), and only a slight association (.012) for non-southern states. Similarly, for larceny there is a moderate relationship between income inequality and imprisonment for southern states (.451), and a slight negative association for non-southern jurisdictions $(-.049)$. Comparison of the betas show that the region-income inequality variable is the best predictor of imprisonment for larceny, and the second best predictor (behind the percentage of residents living in large cities) for burglary.

For the remaining offenses there is no consistent pattern of regional effects upon the relationship between income inequality and imprisonment. For auto theft there is a slight positive relationship between income inequality and the dependent variable for both southern (.217) and nonsouthern states (.214), whereas for murder, income inequality and imprisonment ratios are negatively associated for southern $(-.194)$ and non-southern $(-.079)$ jurisdictions. Finally, for assault there is a slight negative relationship between income inequality and imprisonment for southern states (and a slight positive relationship between these two factors in non-southern states), but this pattern is reversed for robbery.

For Model III, where the index crime rate for 1959 and percent non-white population are introduced as control variables, the findings are also mixed, and even more unfavorable for the conflict hypothesis. For larceny, there remains a significant interaction effect between region and income inequality, with income inequality being a much better predictor of imprisonment in 
southern (.537) than non-southern (.005) states. Unlike Model II, however, the index crime rate for 1959 and percent non-white population reduced to insignificance the interaction effect between region and income inequality for burglary. As in Models I and II, only the percentage of state residents living in large cities is a significant predictor of imprisonments for this offense.

As with Model II, the effect of region on the relationship between income inequality and imprisonment is mixed for the other offenses. For southern states, there is a slight positive relationship between income inequality and imprisonment for robbery and auto theft, but a slight negative relationship between these two variables for murder and assault. In contrast, and with the exception of robbery, there is a low positive relationship between income inequality and imprisonment for murder, assault, and auto theft for non-southern states.

Also at odds with the conflict argument is the fact that percent non-white population (race) is not significantly related to imprisonment ratios for any of the six offenses. Moreover (and contrary to our hypothesis), non-white population and imprisonment ratios are negatively associated for four offenses: murder, assault, robbery, and larceny.

Finally, Model III provides some support for the system overload hypothesis that the level of crime affects the ability of the criminal justice system to effectively respond to crime. For each offense, the higher the index crime rate (1959), the lower the imprisonment ratio (1960). For murder $(-.643)$ and robbery $(-.680)$, these two factors are significantly related. The coefficient for auto theft $(-.567)$ is also substantial, but falls short of the .05 level of significance. For murder and robbery, the index crime rate is the best predictor of imprisonment. For auto theft, this factor ranks second behind the resource level variable. In contrast, there is only a slight negative trade-off between the crime rate and imprisonment ratios for assault, burglary and larceny.

\section{Results For A Reduced Model}

While the above results provide only limited support for the conflict hypothesis for income inequality and no support for the conflict hypothesis for race, the possibility exists that I have not properly specified the imprisonment rate equations. Note that some variables were not significantly related to imprisonment ratios for any offense for any model, while some other variables were significant predictors of imprisonment for only some offenses. By retaining nonsignificant variables throughout the analysis (Models I, II, and III), degrees of freedom were reduced, thus making it more difficult to establish a statistically significant finding for the variables of primary interest, income inequality, and non-white population.

To test this question, imprisonment rates for each offense were regressed against income inequality (or the region-income inequality variable) and non-white population, and any other variable examined in Model III that reached the .10 level of statistical significance. (A liberal .10 level of significance was chosen because of the ratio of the number of independent variables to observations considered in Model III.) Accordingly, the predictor variables considered in the reduced models differ by offense. Results of this analysis are shown in Table $2 .{ }^{8}$

Table 2 provides only limited support for the conflict argument. Percent non-white population is not a significant predictor of imprisonment for any offense: the coefficients for race are mixed in sign and low in magnitude. Similarly, for murder, robbery, auto theft, and assault, where income inequality is considered (rather than the interaction variable for region and income inequality), the betas are mixed in sign and low in magnitude. For murder, robbery, and auto theft, the index crime rate is a significant predictor of imprisonment, along with the resource level

8. In Table 2, the region-income inequality interaction variable is considered solely for burglary and larceny, since the results for this variable were not statistically significant $(P<.10)$ in the earlier analysis (Model III) for the other offenses. 
TABLE 2

Multiple Regression Results for Reduced Models of

Imprisonment Ratios for Six Index Offenses, 1960

\begin{tabular}{|c|c|c|c|c|c|c|}
\hline Independent Variables & Murder & Assault & Robbery & Burglary & Larceny & $\begin{array}{l}\text { Auto } \\
\text { Theft }\end{array}$ \\
\hline Economic Inequality (Gini) & -.149 & .129 & -.107 & $* \star *$ & $* * *$ & .132 \\
\hline Percent Non-White Population & -.115 & -.330 & .079 & .302 & -.188 & .019 \\
\hline Economic Inequality \& Region & $\ldots$ & $* * *$ & $\ldots$ & .374 & $.522 a$ & $\ldots$ \\
\hline Southern States & & & & .296 & .766 & \\
\hline Non-Southern States & & & & -.078 & .244 & \\
\hline Percent Residents of Large Cities & $\ldots *$ & $* * *$ & *** & $-.572 c$ & $\ldots$ & $\ldots$ \\
\hline Resource Level (Per Capita Income) & $* * *$ & $* * *$ & $\star \star * *$ & $* * *$ & $\star * *$ & $.516 \mathrm{a}$ \\
\hline Index Crime Rate, 1959 & $-.370 a$ & ** & $-.486 b$ & $* *$ & *** & $-.365 a$ \\
\hline $\mathrm{R}^{2}$ & $.201 a$ & .066 & $.21 € \mathrm{a}$ & $.559 \mathrm{c}$ & $.369 c$ & .137 \\
\hline
\end{tabular}

Significance Levels: $\mathrm{a}=\mathrm{P}<.05 ; \mathrm{b}=\mathrm{P}<.01 ; \mathrm{c}=\mathrm{P}<.001$.

$\star *$ Variables not included in the model for the offense indicated.

variable for auto theft. None of the independent variables are significantly related to imprisonments for assault.

For burglary and larceny, where the region-income inequality variable was examined, the findings closely parallel the earlier results (Model III). For larceny, there is a significant interaction effect between region and income inequality, with income inequality a better predictor of imprisonment for southern (.766) than non-southern (.244) states. This finding is consistent with Jacobs' early study. In contrast, the reduced model fails to show a significant interaction effect at the .05 level between region and income inequality for burglary. Note, however, that income inequality is positively associated with imprisonment ratios for southern states (.296), and negatively associated with imprisonments for non-southern states $(-.078)$.

To sum up, the above analysis (Tables 1 and 2) reveals a generally stable pattern of findings for the conflict hypothesis. First, for none of the six offenses is race (non-white population) a significant predictor of levels of imprisonment. Second, with the exception of larceny, income inequality is also not a significant predictor of levels of imprisonment. Even for larceny, however, there is not a direct relationship between income inequality and state imprisonment ratios. The relationship depends upon region, with income inequality only predicting levels of imprisonment in southern states. This finding contradicts Jacobs' argument that income inequality should have a relatively uniform effect on imprisonment throughout the states since the "affluent are evidently the most frequent victims of larceny in all regions of the country" (1978:521).

\section{SUMMARY AND CONCLUSION}

This investigation extends the scope of Jacobs' (1978) study. From a cross-sectional analysis of states for 1960 , Jacobs finds that income inequality is a significant determinant of imprisonment ratios for burglary and larceny, and concludes that "conflict theory does predict outcomes in the criminal justice system when property is at stake" (1978:523). Jacobs contends that these findings challenge Chirico's and Waldo's (1975:769) assertion that the available evidence consistently fails to support the expectations of conflict theorists with regard to the sanctioning power of the state. Jacobs' study suffers from a number of limitations, however, and my replication and extension of his analysis does not support the conflict hypothesis for either crimes against persons or property.

In summary, these are my findings:

1) There is a slight negative relationship between income inequality and imprisonment ratios for murder and robbery, and a slight positive relationship between income inequality and imprisonment ratios for assault and auto theft. For none of these offenses are the results statistically 
significant, nor is there any evidence of a significant interaction effect between region and income inequality and imprisonment ratios for these offenses.

2) For burglary and larceny, there is a more substantial relationship between income inequality and imprisonment ratios, but this relationship depends upon region. For both offenses, income inequality is a better predictor of levels of imprisonment for southern than non-southern states. The interaction effect between income inequality and region is statistically significant for larceny.

3) Non-white population (race) is negatively associated with imprisonment ratios for murder, assault, and larceny, and positively associated with levels of imprisonment for robbery, burglary, and auto theft. Regardless of their sign, however, the coefficients for non-white population are low in magnitude and are not statistically significant.

This analysis provides no support for the conflict hypothesis, with the exception of the significant $(\mathrm{P}<.05)$ positive relationship between income inequality and imprisonment for larceny. Even this relationship, however, depends on region, with income inequality being a better predictor of imprisonment for southern (beta $=.766$ ) than non-southern (beta $=.244$ ) states. In other words, it would appear that the conflict hypothesis for income inequality only holds for larceny for southern states. ${ }^{9}$

I can provide no satisfactory explanation for this finding, but offer two possible hypotheses:

1) If "economic advantage and power only predict imprisonment ratios for a crime of which a disproportionate number of victims are affluent" (Jacobs, 1978:522), then my contradictory findings for larceny for southern and non-southern states may be a result of a different pattern of victimization of the affluent in the two regions of the country. That is, the affluent may be more likely victims of larceny in southern states. This hypothesis is not borne out by the victimization data that Jacobs reports (1978:521). On the contrary, the proportion of people with incomes above $\$ 10,000$ in 1966 that were victims of larceny was 18.3 percent in southern states and 19.2 percent in non-southern states. Similarly, the proportion of people in the second-highest income category $(\$ 6,000-9,999)$ that were victims of larceny was 12.0 percent in southern states and 16.0 percent in non-southern states. While these percentage differences are not large, if anything Jacobs' argument would lead us to expect income inequality to be a better predictor of imprisonment for larceny in non-southern jurisdictions.

2) There may be a non-linear relationship between income inequality and imprisonment for larceny, with this relationship being qualitatively different for the two regions. Specifically, income inequality may have to reach a certain level-a "tipping point"-before it has a significant effect on imprisonment ratios, and this point may be reached in southern, but not in nonsouthern, states.

To explore this possibility, I examined the level of income inequality for the two regions of the country. For non-southern states, the Gini coefficients range from .312 to .391 , with a mean value of .346. For southern states, the Gini coefficients range from .349 to .466 , with a mean value of .410 . These Gini values indicate that not only is the range of income inequality greater in southern (.117) than non-southern (.079) states, but that the absolute level of income inequality is greater in southern states.

This regional pattern may possibly account for the fact that income inequality is a better predictor of imprisonment for larceny in southern states. Support for this interpretation is provided by Jacobs' argument that "the more there are differences in economic resources and

9. Note that these findings are not unique to 1960 . Rather, a replication of the analysis for 1964 also shows a significant $(P<.01)$ positive relationship between income inequality and the imprisonment ratio for larceny, with the association between these two variables being more substantial in southern (beta $=.387$ ) than nonsouthern (beta $=.049$ ) states. Also, as in 1960 income inequality is not a significant predictor of imprisonment ratios for the remaining index offenses for 1964 . Nor is non-white population significantly related to imprisonment for any offense. Results of the 1964 analysis are available from the author upon request. 
economic power, the more one can expect that the criminal codes will be administered in a way that pleases monied elites," and "one major guarantee of the supremacy of an economic elite is property" (1978:516). If this interpretation is correct, however, one must ask why income inequality only significantly predicts imprisonments for larceny in southern states. Are not burglary, auto theft, and robbery (and possibly even murder and assault) also threats to the interests of the monied elite in southern states?

My analysis suggests the answer to this question is negative. For no crime against property other than larceny is there a significant interaction effect between income inequality and region on imprisonment ratios. If anything, one would expect such a finding for burglary, since those at high income levels (above $\$ 10,000$ ) are more likely to be victims of this offense in southern $(8.5$ percent) than non-southern (6.6 percent) states (Jacobs, 1978:521). This prediction, however, is not borne out by the regression analysis.

Contrary to the conflict hypothesis and Jacobs' argument, and whereas the more affluent in the South have a higher victimization rate for burglary than their non-southern counterparts, income inequality is not a significant predictor of imprisonment for burglary in southern states. Conversely, whereas the more affluent in the South have a lower victimization rate for larceny than their non-southern counterparts, income inequality is a significant predictor of imprisonment for larceny in southern states. Unfortunately, adequate data are not available for the period under study to examine regional patterns of victimization by income for the remaining crimes against property and persons considered in the analysis (Ennis, 1967). However, this is probably not an important consideration since there is no evidence of a significant interaction effect between region and income inequality on imprisonment ratios for these offenses.

I can provide no adequate explanation of why the relationship between income inequality and imprisonment for larceny is conditioned by region, with inequality only being a good predictor of imprisonment in the South. What is clear, however, is that this regional difference is not a result of lower rates of victimization for larceny of the affluent in non-southern states. Nor would this finding appear to be a result of a general southern response to property crimes and inequality, since this regional pattern is unique to larceny.

The evidence presented in this analysis for both race and income inequality overwhelmingly refutes Jacobs' argument that "conflict theory does predict outcomes in the criminal justice system when property is at stake." I agree with Jacobs, however, that "it would be naive to expect that the evidence from any single research design can settle the dispute between conflict and consensus theorists" (1978:523). This is certainly true of his study, and is no less the case with mine. I must, however, take strong issue with Jacobs' claim that his research successfully challenges - at least for property crimes-critics of the conflict hypothesis. Rather, the support that Jacobs reports for the conflict hypothesis would appear to be a consequence of the theoretical and methodological shortcomings of his analysis.

\section{REFERENCES}

Chiricos, Theodore and Gordon P. Waldo

1975 "Socioeconomic status and criminal sentencing." American Sociological Review 40:753-772.

Ehrlich, Isaac

1973 "Participation in illegal activities: A theoretical and empirical investigation." Journal of Political Economy 81:521-565.

1975 "The deterrent effect of capital punishment: A question of life and death." American Economic Review 65:379-417.

Ennis, Philip H.

1967 Criminal Victimization in the United States: A Report of a National Survey. Washington, D.C.: U.S. Government Printing Office.

Farrar, Donald and Robert Glauber

1967 "Multicollinearity in regression analysis: The problem revisited." Review of Economics and Statistics XLIX: 92-107. 
Federal Bureau of Investigation

1959- Uniform Crime Reports. Washington, D.C.: U.S. Government Printing Office. 1960

Federal Bureau of Prisons

No National Prisoner Statistics: Characteristics of State Prisoners, 1960. Washington, D.C.: Federal date Bureau of Prisons.

Fisher, Franklin M. and Daniel Nagin

1978 "On the feasibility of identifying the crime function in a simultaneous model of crime rates and sanction levels.” Pp. 361-399 in Alfred Blumstein, Jacqueline Cohen, and Daniel Nagin (eds.), Deterrence and Incapacitation: Estimating the Effects of Criminal Sanctions on Crimes. Washington, D.C.: National Academy of Sciences.

Greenberg, David F., Ronald C. Kessler, and Charles H. Logan

1980 "Crime rates and arrest rates: A causal analysis." American Sociological Review 44:843-850.

Haitovsky, Yoel

1969 "Multicollinearity in regression analysis: Comment." Review of Economics and Statistics LI:486-489.

Jacobs, David

1978 "Inequality and the legal order: An ecological test of the conflict model." Social Problems 25:515-525.

Janish, James E. and James B. Kau

1973 "State differentials in income inequality." Review of Social Economy 31:179-190.

Logan, Charles $\mathrm{H}$.

1972 "General deterrent effects of imprisonment." Social Forces 51:64-73.

1975 “Arrest rates and deterrence." Social Science Quarterly 56:376-389.

Nagin, Daniel

1978 "Crime rates, sanction levels, and constraints on prison population." Law and Society Review $12: 341-366$.

Office of Business Economics, U.S. Department of Commerce

1966 Survey of Current Business. August.

U.S. Bureau of the Census, Department of Commerce

1961 State Distribution of Public Employment in 1960. Washington, D.C.: U.S. Government Printing Office.

1964 United States Census of Population: 1960. Volume I, Characteristics of the Population. Washington, D.C.: U.S. Government Printing Office. 